\title{
Large-scale atmospheric dynamics of the wet winter 2009-2010 and its impact on hydrology in Portugal
}

\author{
Cristina Andrade ${ }^{1,2, *}$, João A. Santos ${ }^{3}$, Joaquim G. Pinto ${ }^{4}$, João Corte-Real ${ }^{2}$ \\ ${ }^{1}$ Polytechnic Institute of Tomar, Quinta do Contador, Estrada da Serra, 2300-313 Tomar, Portugal \\ ${ }^{2}$ Institute of Mediterranean Agrarian and Environmental Sciences (ICAAM), Group Water, Soil and Climate, \\ University of Évora, Núcleo da Mitra, Apartado 94, 7002-774 Évora, Portugal \\ ${ }^{3}$ CITAB, University of Trás-os-Montes e Alto Douro, 5001-801 Vila Real, Portugal \\ ${ }^{4}$ Institute for Geophysics and Meteorology, University of Cologne, Kerpener Str. 13, 50923 Cologne, Germany
}

\begin{abstract}
The anomalously wet winter of 2010 had a very important impact on the Portuguese hydrological system. Owing to the detrimental effects of reduced precipitation in Portugal on the environmental and socio-economic systems, the 2010 winter was predominantly beneficial by reversing the accumulated precipitation deficits during the previous hydrological years. The recorded anomalously high precipitation amounts have contributed to an overall increase in river runoffs and dam recharges in the 4 major river basins. In synoptic terms, the winter 2010 was characterised by an anomalously strong westerly flow component over the North Atlantic that triggered high precipitation amounts. A dynamically coherent enhancement in the frequencies of mid-latitude cyclones close to Portugal, also accompanied by significant increases in the occurrence of cyclonic, south and southwesterly circulation weather types, are noteworthy. Furthermore, the prevalence of the strong negative phase of the North Atlantic Oscillation (NAO) also emphasises the main dynamical features of the 2010 winter. A comparison of the hydrological and atmospheric conditions between the 2010 winter and the previous 2 anomalously wet winters (1996 and 2001) was also carried out to isolate not only their similarities, but also their contrasting conditions, highlighting the limitations of estimating winter precipitation amounts in Portugal using solely the NAO phase as a predictor.
\end{abstract}

KEY WORDS: Winter 2010 - Precipitation · Large-scale dynamics · Water cycle · North Atlantic Oscillation · Portugal

\section{INTRODUCTION}

Recent heat waves and droughts, as well as cold spells, wind storms and floods have raised public awareness about extreme meteorological events and their environmental and social-economical impacts. Extreme events not only have a great impact on agricultural production, but can also influence energy production and demand. Such natural hazards also have an effect on infrastructures and human activities, cost billions of euros and cause human casualties (e.g. Ulbrich et al. 2003, García-Herrera et al. 2007, 2010, Fink et al. 2009). As such, the assessment of the impacts of extreme events is of utmost relevance for policymakers, decision-makers and stakeholders, as a valuable tool in developing suitable adaptation and mitigation measures, which hopefully reduce their harmful effects.

Precipitation extremes are very relevant for the Iberian Peninsula. Previous studies have shown a strong relationship between Iberian precipitation regimes and large-scale atmospheric circulation (e.g. Ulbrich et al. 1999, Trigo \& DaCamara 2000, Santos et al. 2007b). Due to the strong seasonality and large inter-annual variability of the Iberian rainfall (typical Mediterranean-like conditions), winter precipitation (DJF) is by far the most important contributor to the total annual precipitation (e.g. Sáenz et al. 2001, Paredes et al. 2006, Santos et al. 2009a), largely affecting river runoffs and dam storages (e.g. Pereira et al. 2002) and also playing a key role in triggering hydrological droughts (e.g. Santos et al. $2009 b)$. This precipitation regime thus has a great im- 
pact on water resource management and on water quality in Portugal, and explains the high vulnerability of the country to wintertime rainfall occurrence and respective amounts.

In recent years, several studies have extensively addressed the drought processes in the Iberian Peninsula (Vicente-Serrano 2006a,b, García-Herrera et al. 2007, Santos et al. 2007a). Most of them analysed winter precipitation and its relationships with the largescale atmospheric circulation (Zorita et al. 1992, Ulbrich et al. 1999, Goodess \& Jones 2002, Santos et al. 2009b, Andrade et al. 2010). In particular, the occurrence of severe precipitation deficits (and thus droughts) in Portugal was specifically related to the development of strong and persistent anticyclonic ridge episodes over the eastern North Atlantic (Santos et al. 2009a). The severity of the winter precipitation deficits also has a great impact on the terrestrial branch of the hydrological cycle, mainly due to the resulting water storage deficits (Trigo et al. 2004).

In the perception of the Portuguese authorities and of society in general, the 2010 winter was exceptionally rainy, but had important beneficial socio-economic impacts. For example, a significant increase in the hydroelectric power generation was reported (about $\pm 30 \%$ of the total electric energy production in an average year). Owing to the relevance of this particular winter to many environmental and socio-economic systems in Portugal, the current study aimed not only to identify the large-scale atmospheric patterns that contributed to the above-average precipitation over Portugal, but also to characterise some of the resulting effects on the terrestrial branch of the hydrological system, including its role in offsetting the accumulated water deficits of previous years. With this aim, runoffs and dam recharges (essential components of the water cycle) in the 4 major river basins in Portugal were considered. Finally, the hydrological and atmospheric characteristics of the 2010 winter were compared with 2 previous anomalously wet winters (1995/96 and 2000/01, hereafter 1996 and 2001 winters).

This manuscript is organised as follows: in Section 2, data and methodology are described; Section 3 describes the main results, with particular emphasis on the hydrological and dynamical diagnosis of 2010 winter conditions, also giving a relative overview of this winter with respect to other recent wet winters. Section 4 summarises and discusses the main conclusions.

\section{DATA AND METHODS}

Monthly precipitation totals recorded at 3 weather stations (Porto, Lisboa and Beja) in Portugal were used to estimate the severity of the 2010 winter. These 3 sta- tions are representative of the whole country, as Porto is located in the north, Lisboa in central Portugal and Beja in the south (cf. Fig. 2 in Santos et al. 2009b). These meteorological data were provided by the European Climate Assessment \& Dataset project (Klein Tank et al. 2002). Data from 1942-2010, i.e. the maximum available length common to the 3 stations, were used in the subsequent analyses.

The hydrological characterisation was improved by the estimation of evaporation and subterranean recharges across the entire Iberian Peninsula. Note that the major river basins in Portugal are not exclusively confined to the Portuguese mainland (except the Mondego River), but extend over large areas of the Iberian Peninsula. The Turc (1954) empirical formula is amongst the simplest mathematical expressions for estimating annual evaporation. Furthermore, under humid conditions, it can also be used to estimate winter evaporation. This equation is expressed as:

$$
E=\frac{P}{\sqrt{0.9+\frac{P^{2}}{L(T)^{2}}}}
$$

where $E$ is the annual evaporation $(\mathrm{mm}), P$ is annual precipitation $(\mathrm{mm}), T$ is annual mean air temperature $\left({ }^{\circ} \mathrm{C}\right)$ and

$$
L(T)=300+25 T+0.05 T^{2}
$$

The subterranean recharge (SR) was estimated by the following equation:

$$
\mathrm{SR}=P-E-0.1(P-E)
$$

Annual values of precipitation and air temperature were computed using gridded daily precipitation totals and daily mean air temperature in the entire available period (1950-2010) and defined on a grid of $0.25^{\circ}$ latitude $\times 0.25^{\circ}$ longitude. These data were retrieved from the E-OBS dataset, produced by the EU-FP6 ENSEMBLES project and provided by the ECA\&D project (Haylock et al. 2008).

Complementary hydrological data for the 4 major river basins in Portugal, 1 located in northern Portugal (Douro), 2 in central Portugal (Mondego and Tejo) and 1 in the south (Guadiana) were retrieved from the Sistema Nacional de Informação de Recursos Hídricos (SNIRH). For the Douro, Tejo and Guadiana hydrological basins, only their Portuguese parts were considered. Due to the lack of complete and long records, only time series in the period 1990-2010 and for the most reliable stations were considered here. General information concerning the selected stations and dams, along with the corresponding water recharges at the end of February 2010 in the aforementioned river basins are shown in Table 1 and Fig. 1. 
Table 1. River stations within the corresponding 4 river basins (see Fig. 1 for geographical locations), along with the respective dam recharges at the end of February (in \%). Dam recharges are separated in 2 classes: above $80 \%$ and between 50 and $80 \%$

\begin{tabular}{|c|c|}
\hline $\begin{array}{l}\text { River basin (station) } \\
\text { Dam }\end{array}$ & Recharge \\
\hline \multicolumn{2}{|c|}{ Douro (Miranda, Torrão, Pocinho) } \\
\hline \multicolumn{2}{|c|}{$80 \%$} \\
\hline Alijó & 100 \\
\hline Azibo & 90.2 \\
\hline Torrão & 81.3 \\
\hline Varosa & 100 \\
\hline Vilar-Tabuaço & 97.8 \\
\hline \multicolumn{2}{|c|}{ Mondego (Açude Ponte, Aguieira) } \\
\hline \multicolumn{2}{|l|}{$80 \%$} \\
\hline Caldeirão & 96.9 \\
\hline Lagoa Comprida & 93.8 \\
\hline \multicolumn{2}{|l|}{$50-80 \%$} \\
\hline Aguieira & 78.4 \\
\hline Fronhas & 73.3 \\
\hline Vale do Rossim & 63.1 \\
\hline \multicolumn{2}{|c|}{ Tejo (Cabril, Fratel, Almourol, Montargil) } \\
\hline \multicolumn{2}{|l|}{$80 \%$} \\
\hline Apartadura & 95.6 \\
\hline Cabril & 97.1 \\
\hline Castelo de Bode & 92 \\
\hline Cova do Viriato & 100 \\
\hline Idanha & 100 \\
\hline Magos & 100 \\
\hline Maranhão & 100 \\
\hline Meimoa & 86.5 \\
\hline Montargil & 100 \\
\hline Póvoa & 83.7 \\
\hline Pracana & 94.7 \\
\hline Sta Águeda-Marateca & 100 \\
\hline \multicolumn{2}{|l|}{$50-80 \%$} \\
\hline Divor & 62.5 \\
\hline \multicolumn{2}{|c|}{ Guadiana (Vendinha, Monte da Vinha, Monte dos Fortes) } \\
\hline \multicolumn{2}{|l|}{$80 \%$} \\
\hline Alqueva & 100 \\
\hline Beliche & 83.1 \\
\hline Enxoé & 100 \\
\hline Lucefecit & 100 \\
\hline Monte Novo & 88.9 \\
\hline Odeleite & 96.5 \\
\hline Vigia & 98.2 \\
\hline \multicolumn{2}{|l|}{$50-80 \%$} \\
\hline Caia & 72.3 \\
\hline
\end{tabular}

Meteorological variables were obtained from the National Centers for Environmental Prediction \& National Center for Atmospheric Research (NCEP/NCAR) reanalysis project (Kistler et al. 2001): mean sea level pressure (MSLP), geopotential height, precipitation rate, zonal and meridional wind components at 250 and $850 \mathrm{hPa}$ and specific humidity at $850 \mathrm{hPa}$. The

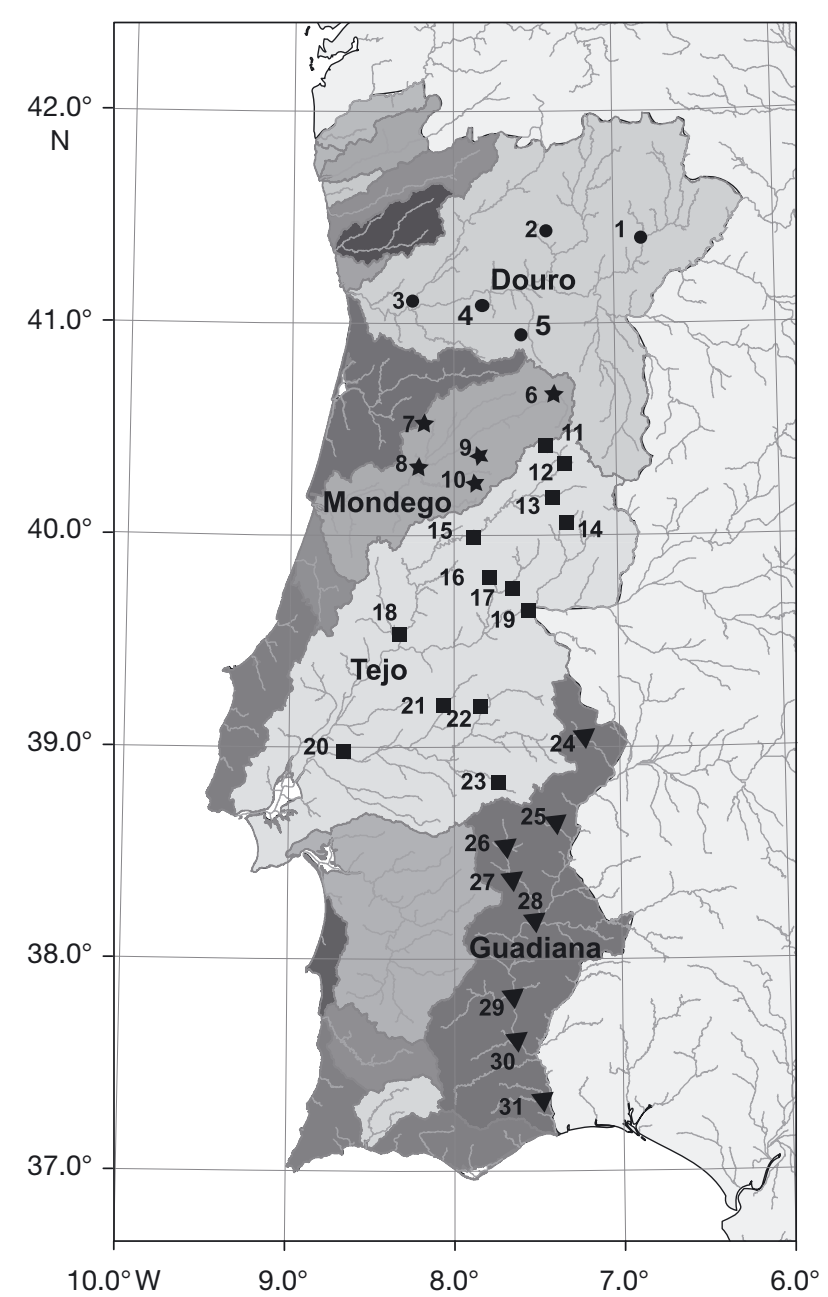

Fig. 1. Geographical locations of the river stations within the corresponding river basins (circles, Douro; stars, Mondego; squares, Tejo; triangles, Guadiana) presented in Table 1. 1: Azibo, 2: Alijó, 3: Torrão, 4: Varosa, 5: Vilar Tabuaço, 6: Caldeirão, 7: Aguieira, 8: Fronhas, 9: Vale de Rossim, 10: Lagoa Comprida, 11: Cova do Viriato, 12: Meimoa, 13: Sta Águeda-Marateca, 14: Idanha, 15: Cabril, 16: Pracana, 17: Póvoa, 18: Castelo de Bode, 19: Apartadura, 20: Magos, 21: Montargil, 22: Maranhão, 23: Divor, 24: Caia, 25: Lucefecit, 26: Vigia, 27: Monte Novo, 28: Alqueva, 29: Enxoé, 30: Odeleite, 31: Beliche (figure adapted from http://snirh.pt/)

atmospheric fields are defined on a grid of $2.5^{\circ}$ latitude $\times 2.5^{\circ}$ longitude, and data were extracted for the full available time period (1949-2010). The dynamical diagnosis was further improved by considering winter means of the North Atlantic Oscillation (NAO) index and of the Arctic Oscillation (AO) index, obtained from the Climate Diagnostic Center at NCEP (1949-2010). Many previous studies have discussed in great detail the definitions of these oscillations, as well as their interrelationship (e.g. Hurrell 1995, Thompson \& Wallace 1998). 
Large-scale atmospheric circulation over Portugal was also classified using the objective scheme described by Jenkinson \& Collison (1977), which is based on the empirical Lamb weather types (Lamb 1972). Originally developed for the British Isles, it was later applied to other European regions (e.g. Buishand \& Brandsma 1997), including Portugal (e.g. Trigo \& DaCamara 2000). Flow characteristics were calculated taking into account the geostrophic approximation and were based on the reanalysed MSLP fields, defined on a surrounding $2.5^{\circ} \times 2.5^{\circ}$ grid centred at $40^{\circ} \mathrm{N}, 10^{\circ} \mathrm{W}$ (cf. Fig. S1 in Supplement 1, available at www.int-res.com/articles/ suppl/c046p029_supp.pdf). The 00 UTC MSLP fields from the NCEP reanalysis in 1949-2010 were used in the present study. The flow was classified into directional, (anti-) cyclonal (C and A) or hybrid circulation weather types (CWTs). The directional types were divided into 8 angular sectors of $45^{\circ}$ each: NE, E, SE, S, SW, W, NW and N. Thus, the frequencies are given for 10 CWTs (8 directional, 1 cyclonal, 1 anti-cyclonal). In terms of frequency counts, hybrid weather types were weighted as half-day occurrences of the corresponding directional and (anti-)cyclonal types; further details can be found in Jones et al. (1993). The MSLP composites for each CWT and their corresponding MSLP anomalies confirmed their dynamically different structures (cf. Figs. S2, S3 in Supplement 1).

Lastly, cyclone positions and tracks were obtained from MSLP fields. We used an algorithm originally developed by Murray \& Simmonds (1991) and adapted for Northern Hemisphere cyclone properties (Pinto et al. 2005). Cyclones were identified using a proxy of their relative geostrophic vorticity, approximated by the Laplacian of the MSLP (cf. Murray \& Simmonds 1991). Subsequently, a tracking algorithm was applied, taking into consideration the most probable displacement of a cyclone under the given large-scale conditions, previous path and speed. Further details can be found in Murray \& Simmonds (1991), Simmonds et al. (1999) and Pinto et al. (2005). A complete cyclone climatology (omitted here) is presented and discussed by Pinto et al. $(2005,2007)$.

\section{RESULTS}

\subsection{Precipitation, evaporation and subterranean recharge}

Winter (DJF) precipitation totals recorded at Porto, Lisboa and Beja are largely representative of the wintertime inter-annual precipitation variability of the whole country. This assumption is supported by the high correlation coefficients among the 3 time series in the selected time period (1942-2010; 69 winters):
0.93 between Lisboa and Beja; 0.78 between Porto and Lisboa and 0.76 between Porto and Beja; all were statistically significant at a confidence level of $99 \%$. Further, the 3 time series showed similar interannual variability, without relevant point-deviations (not shown).

This similarity is further stressed when the 3 empirical distributions of each winter precipitation time series are fitted to a specific theoretical distribution. In fact, the Johnson-SB family distribution with $\gamma$-shape parameter, $\delta$-shape parameter $(\delta>0), \lambda$-scale parameter, $\xi$-location parameter) provides high-quality adjustments to the empirical distributions of the 3 winter precipitation time series, according to 3 appropriate goodness-of-fit tests (Kolmogorov-Smirnov, AndersonDarling and chi-squared). Johnson-SB is indeed the most suitable theoretical distribution among over 40 tested distributions. The corresponding estimates of the distribution parameters for each time series (standardised to 0-mean and unit variance) are listed in Supplement 2 (available at www.int-res.com/articles/ suppl/c046p029_supp.pdf). The Q-Q plots for the Johnson-SB distribution clearly attest its high skill in representing the empirical distributions of each time series (Fig. 2). Moreover, in northern and central Portugal (Porto and Lisboa), the recorded winter precipitation amounts in 2010 were roughly in the 80th percentile, while in southern Portugal (Beja) it corresponded to the 88th percentile. Hence, our results suggest that the severity of the 2010 winter tended to be more pronounced in southern Portugal than in the northern parts of the country.

The analysis of the total precipitation budgets for each hydrological year (October to September) in the period 1990-2010 and for the 3 selected weather stations revealed several precipitation deficits during the last 2 decades (Fig. 3a). In effect, apart from the extremely rainy hydrological years of 1996, 1998 and 2001, all other hydrological years ended with negative budgets at least in 1 meteorological station (e.g. the 2005 hydrological year was characterised by one of the severest droughts recorded in Portugal; GarcíaHerrera et al. 2007, Santos et al. 2007a). A sequence of several hydrological years with precipitation deficits has important accumulated effects on the entire water cycle, inducing deep changes in its fluxes and in water storages.

As previously mentioned, the amount of winter precipitation is crucial for the total annual precipitation, and thus it has a very strong relevance in the water cycle. The accumulated precipitation deficits are even more apparent when only wintertime precipitation is taken into account (Fig. 3b). In fact, all winters were anomalously dry after 2001, apart from the 2003 winter at Porto. Fortunately, precipitation deficits have been, 

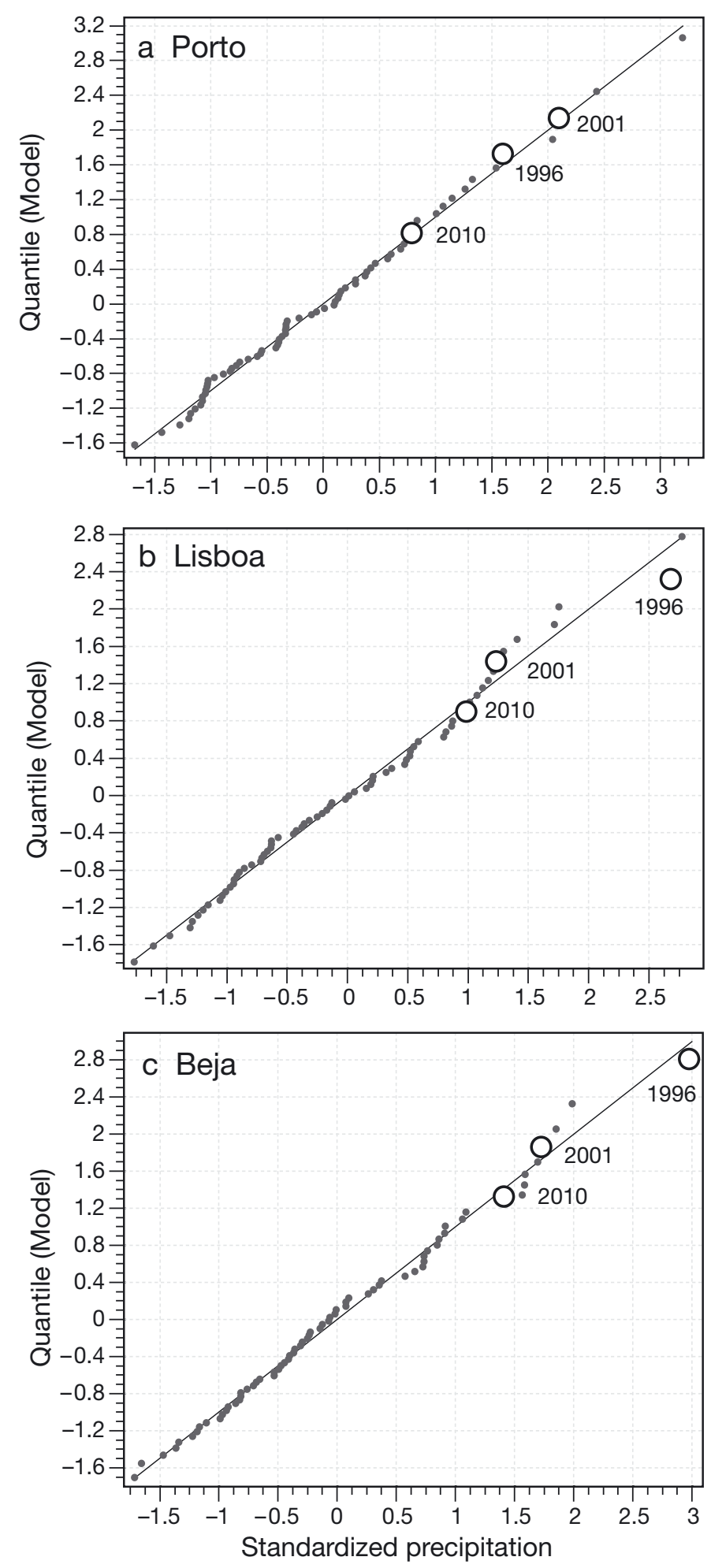

Fig. 2. Q-Q plots for the Johnson-SB distribution of the standardised ( 0 mean and unit variance) winter (DJF) precipitation totals for 1942-2010 at (a) Porto, (b) Lisboa and (c) Beja. The 1996, 2001 and 2010 winters are also pointed out by open circles. The corresponding percentiles are as follows: Porto 2001: 97\%, 1996: 94\%, 2010: $79 \%$; Lisboa 1996: $98 \%, 2001$ : $90 \%$, 2010: $82 \%$; Beja 1996: $100 \%$, 2001: $94 \%$, 2010: $88 \%$

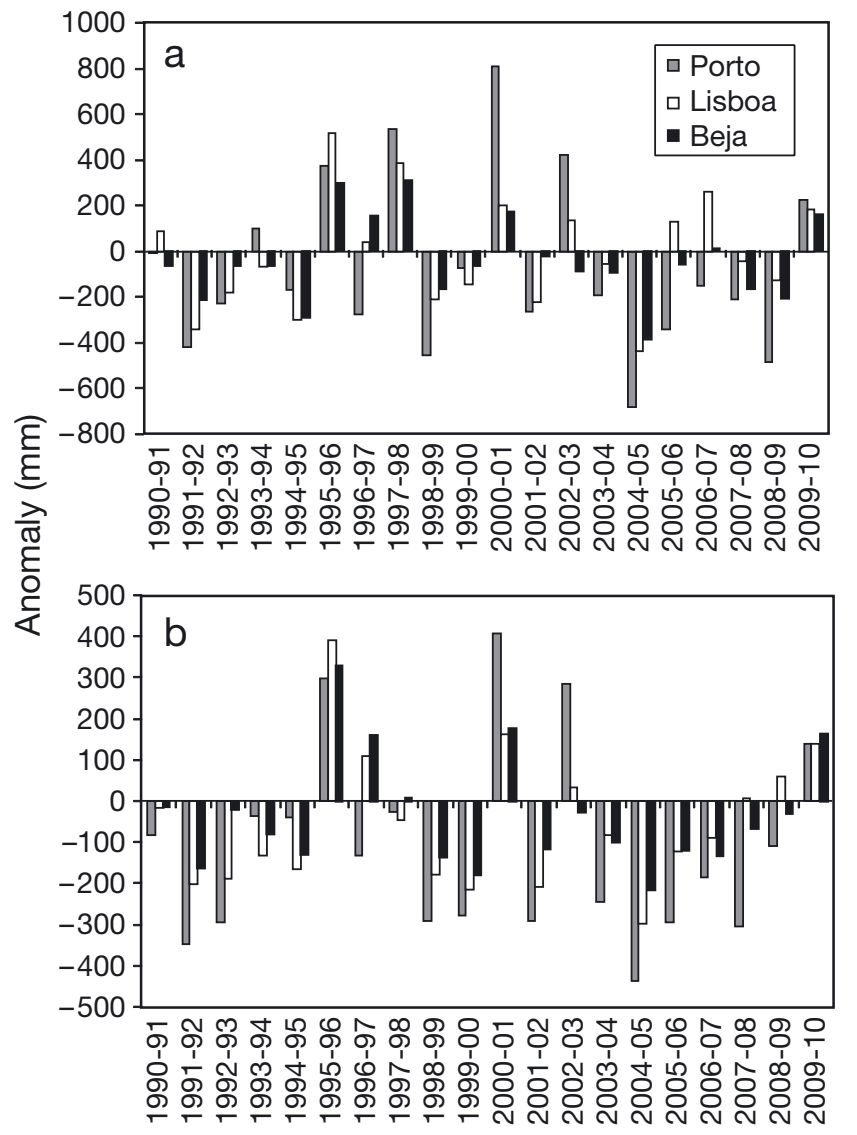

Fig. 3. Total precipitation anomalies (in $\mathrm{mm}$ ) for 1990-2010 in Porto, Lisboa and Beja for (a) the hydrological year (2009-10 from October until March) and for (b) winter (DJF). Anomalies are computed with respect to the climatic normals in 1961-1990

in most of the cases, partially offset by relatively rainy springs and/or autumns (cf. e.g. winter 2007 in Lisbon, Fig. 3a,b). As will be shown below, the precipitation surplus in the 2010 winter was particularly relevant for the convergence of the hydrological fluxes and water storages to their long-term means, reversing the preceding downward trends.

The spatial pattern of the 2010 winter precipitation (Fig. 4a) displays higher amounts over the northwest of Portugal, while the corresponding temperature pattern exhibits higher values southwards (Fig. 4b). Although both fields are in general agreement with the corresponding climate-mean patterns (not shown), there are important positive precipitation anomalies over Portugal, mainly over its southern part, whereas no significant deviations are found in temperature. The very high precipitation amounts over the southernmost regions of Iberia are also noteworthy (Fig. 4a), though they had little relevance for the hydrological conditions in Portugal. 


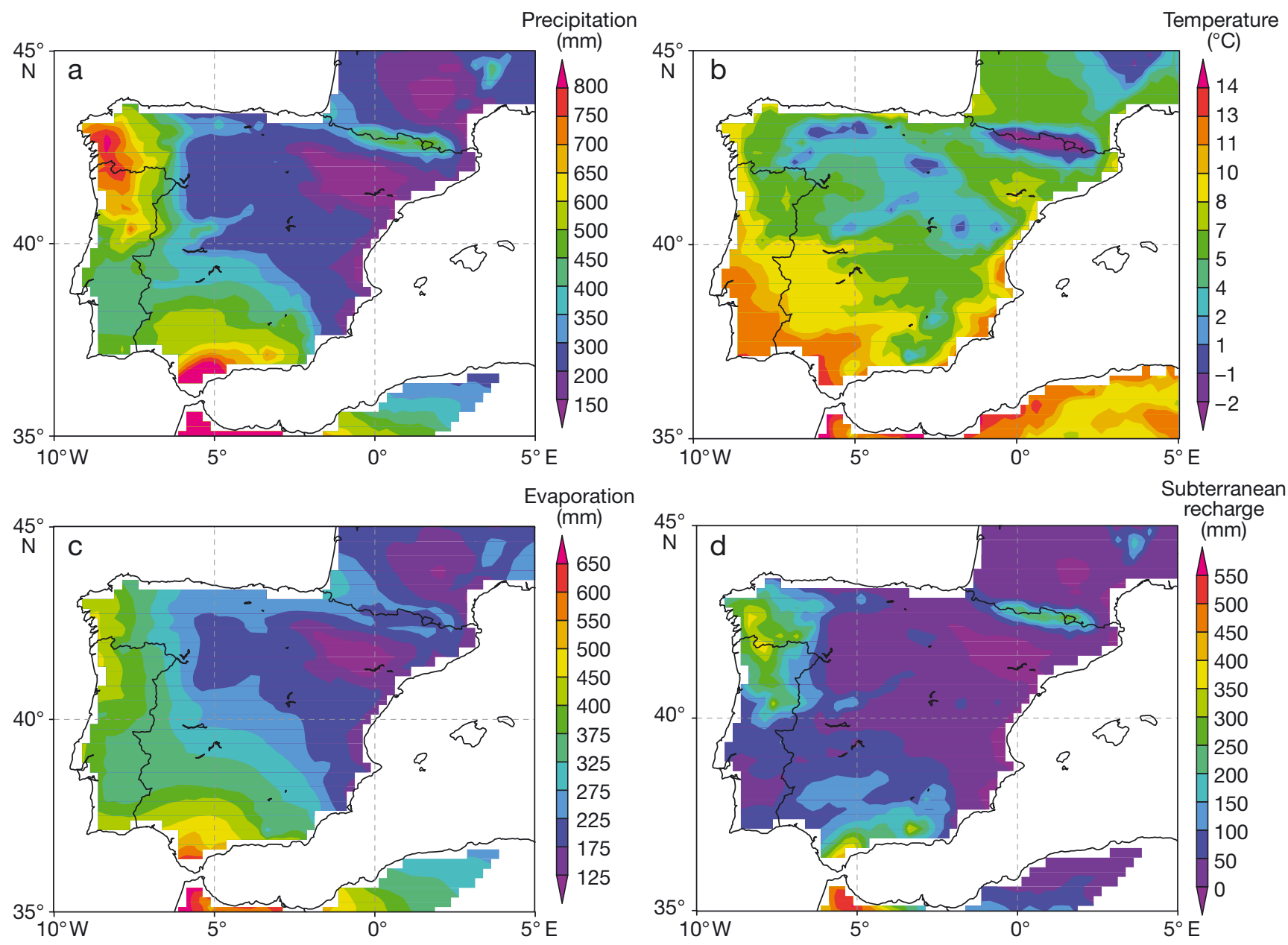

Fig. 4. 2010 winter mean (a) precipitation (in $\mathrm{mm}$ ), (b) temperature (in ${ }^{\circ} \mathrm{C}$ ), (c) estimated evaporation (in $\mathrm{mm}$ ) and (d) subterranean recharge (in $\mathrm{mm}$ )

According to Eqs. (1) and (3), estimations of winter evaporation (Fig. 4c) and subterranean recharges (Fig. 4d) are a direct manifestation of the precipitation and temperature fields (Fig. $4 \mathrm{a}, \mathrm{b})$. In fact, these equations only allow a first-order approximation when estimating evaporation and subterranean recharges, as more accurate estimates would require other parameters such as wind, atmospheric transport of water vapour or upwelling of ground water. Moreover, in line with the precipitation pattern, winter evaporation anomalies also showed positive anomalies in most of Portugal, with the exception of its northernmost region (not shown). Despite the high precipitation amounts recorded during the 2010 winter in Portugal, the resulting enhancement in evaporation largely compensates this precipitation increase. In effect, no significant changes in the subterranean recharges could be identified with respect to their long-term means (not shown). Therefore, the precipitation anomalies were not high enough to yield anomalously high subterranean recharges, but their relatively normal values clearly contrasted with the anomalously low recharges in the previous years (not shown).

\subsection{Dam recharges and runoffs}

Dam recharges and runoffs during the 2010 winter were analysed for the 4 major river basins in the Portuguese mainland. The high precipitation amounts during this winter yielded high dam recharges at the end of February (Table 1, Fig. 1). This result is particularly meaningful when considering the combination of both the previous accumulated precipitation deficit and the increase in the hydroelectric power generation.

All dams analysed in the Douro basin presented recharges above $80 \%$ with respect to their maximum capacity, while in the Tejo and Guadiana basins, all but 1 were above $80 \%$ (Table 1, Fig. 1). The Mondego basin was the exception, were only 2 of the 5 dams 
presented recharge values above $80 \%$, although all of them were clearly above $60 \%$ (Table 1, Fig. 1). The Aguieira dam $\left(3100 \mathrm{~km}^{2}\right)$ represents $46.6 \%$ of the total Mondego basin area $\left(6644 \mathrm{~km}^{2}\right)$, but its area of influence, including the upstream areas of the river catchment and its tributaries, represents $76 \%$ of the total basin area. It thus has a great impact on the downstream runoff and dam recharges. Additionally, its hydroelectric power plant has an important annual average production (209.6 GW h), and the increase in the hydroelectric power production explains the fairly low water storage values in this dam $(78.4 \%)$. Winter mean runoffs are not only representative of each river flow, but also feature a common inter-annual variability, since the correlation coefficients between the runoff series in the selected period (1990-2010) were above 0.99 (statistically significant at a significance level of at least $1 \%$ ), further documenting the leading role of the large-scale atmospheric forcing on wintertime precipitation.

As expected from the winter precipitation budgets (Fig. 3b), anomalously high mean runoffs were achieved during the 2010 winter in all rivers basins (Fig. 5). Therefore, during this winter, Portugal not only experienced a strengthening of the aerial branch of the water cycle (above average precipitation, enhanced evaporation and normal subterranean recharges), but also underwent a clear strengthening of its terrestrial branch (above average runoffs and dam recharges).

\subsection{Meteorological characterisation of the 2010 winter}

We analysed the large-scale atmospheric conditions for the 2010 winter and compared them to their longterm means. For 2010, the typical mid-latitude ridge over the North Atlantic was replaced by a strong westerly flow, as documented by the $250 \mathrm{hPa}$ streamlines and corresponding meridional gradient of the absolute vorticity (Fig. 6a,b). Moreover, the eddy-driven (subpolar) and subtropical jets (their paths tend to follow the maximum gradient axis) were relatively merged when compared to the respective long-term mean field, where there was a clear separation between both jets over the Eastern North Atlantic. The transient-eddy moisture fluxes at $850 \mathrm{hPa}$ were largely coherent with the previous atmospheric dynamical features (Fig. 6c,d), with a significant enhancement of the fluxes over Portugal for 2010 compared to the long-term climatology. The flux convergence over Portugal provided high amounts of moisture for establishing rain-generating mechanisms and resulting strong precipitation amounts under the adequate large-scale forcing (see below).

The maximum precipitation axis was in fact largely zonal, extending towards the Iberian Peninsula, while in climate-mean conditions, it presented a clear southwest-northeast tilt (Fig. 6e,f). Therefore, despite the large amount of uncertainty in the NCEP precipitation rates, they are in clear accordance with the previously
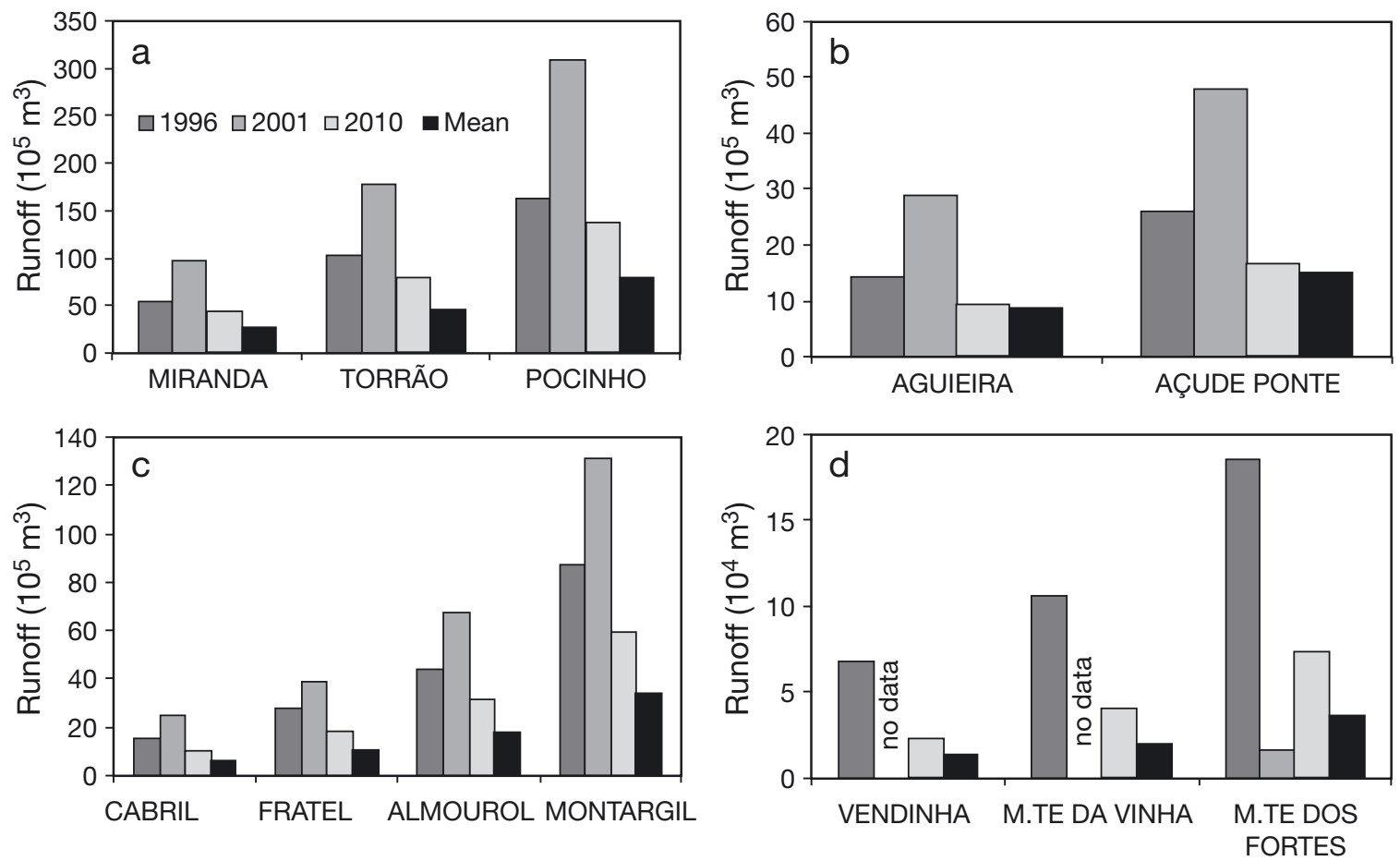

Fig. 5. Winter mean runoffs recorded at 4 river basins for the 1996, 2001 and 2010 winters. The corresponding long-term mean values in 1990-2010 are also plotted (black bars). No data were available for the 2001 winter at 2 stations in the Guadiana basin 
a

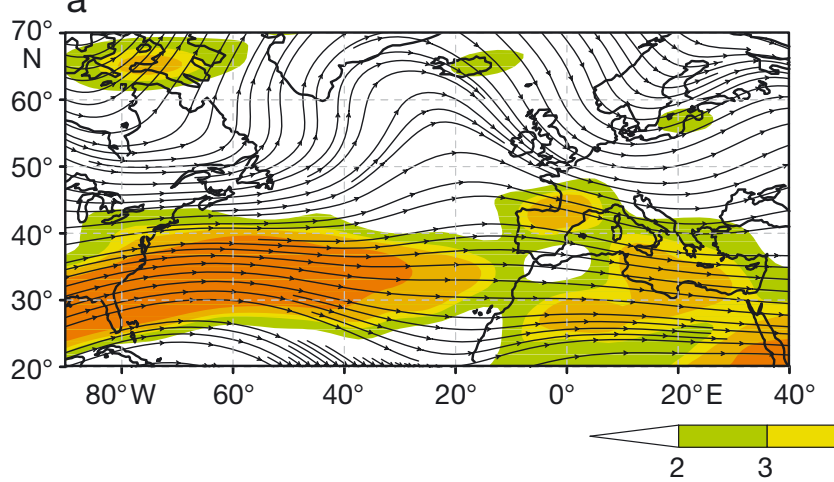

$\mathrm{b}$

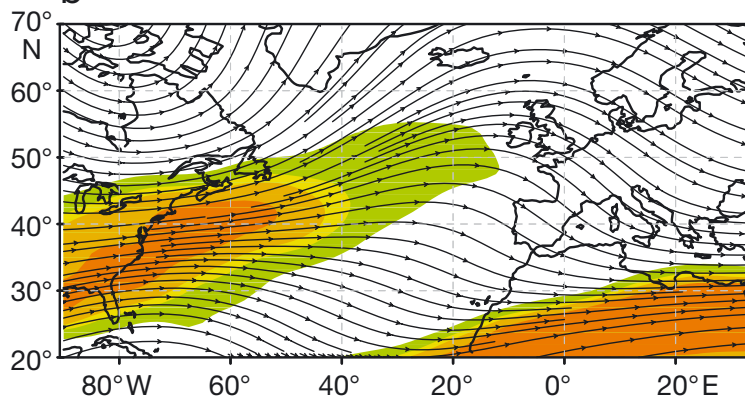

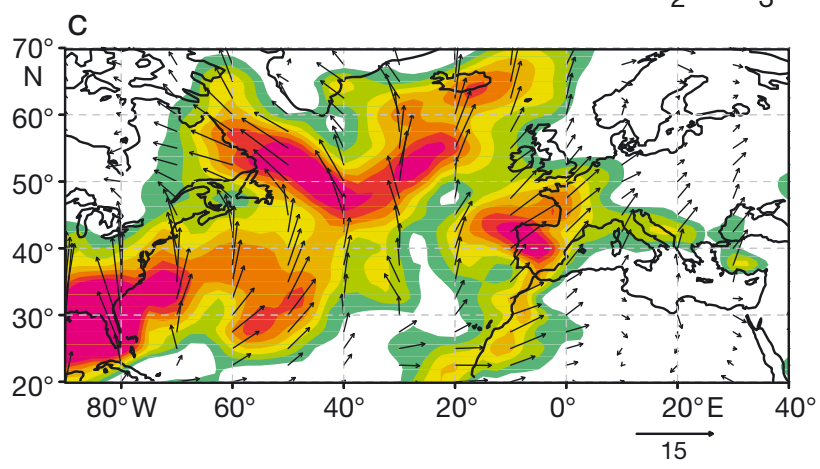

\section{$\mathrm{d}$}
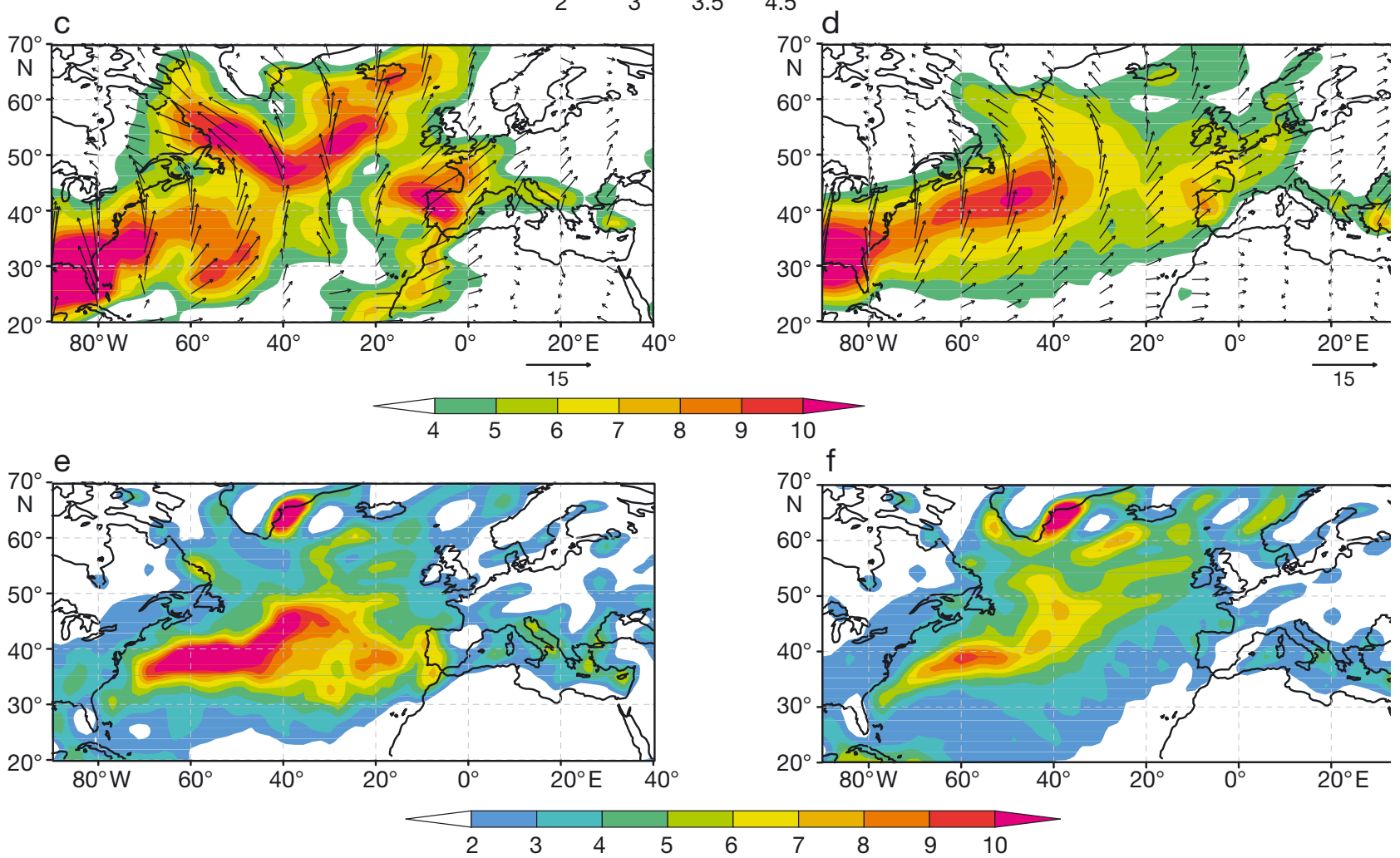

Fig. 6. (a) Streamlines and mean meridional gradient of the absolute vorticity (shading) in $10^{-11} \mathrm{~m}^{-1} \mathrm{~s}^{-1}$ at $250 \mathrm{hPa}$ within the EuroAtlantic sector during the 2010 winter. (c) Transient-eddy horizontal transports of specific humidity within the Euro-Atlantic sector (in $\mathrm{g} \mathrm{kg}^{-1} \mathrm{~m} \mathrm{~s}^{-1}$ ) at $850 \mathrm{hPa}$ during the 2010 winter. Shading represents the intensity of the fluxes and arrows represent the horizontal fluxes. (e) Precipitation rates (in $10^{-5} \mathrm{~mm} \mathrm{~s}^{-1}$ ) within the Euro-Atlantic sector for the 2010 winter. (b, d, f) As on the left, but for the corresponding long-term mean fields in 1949-2010

presented records of high precipitation over Portugal. Furthermore, these patterns suggest that the 2010 precipitation anomalies recorded in Portugal were a result of an uncommon large-scale atmospheric circulation, not being attributable to regional or local effects. This assessment is corroborated by previous studies, where the precipitation regime in Portugal was clearly linked to large-scale atmospheric patterns (Xoplaki et al. 2004, Santos et al. 2005, 2009b, Andrade et al. 2010).

The transient-eddy humidity fluxes are also a manifestation of the presence of synoptic disturbances. In fact, the cyclone distribution for the 2010 winter (Fig. 7a) showed an anomalously high frequency of cyclones tracking near the Iberian Peninsula (and also over the Mediterranean Basin) compared to the long-term climatology, with a clear maximum close to the Portuguese coast (Fig. 7d). As mid-latitude cyclones induce strong vertical atmospheric movements, particularly along their frontal areas, their presence effectively triggers the precipitation events given the above mentioned moisture convergence, thus contributing to the anomalously high precipitation.

Next, the frequencies of occurrence of the CWTs (Table 2) were analysed. Results for 2010 indicate an 


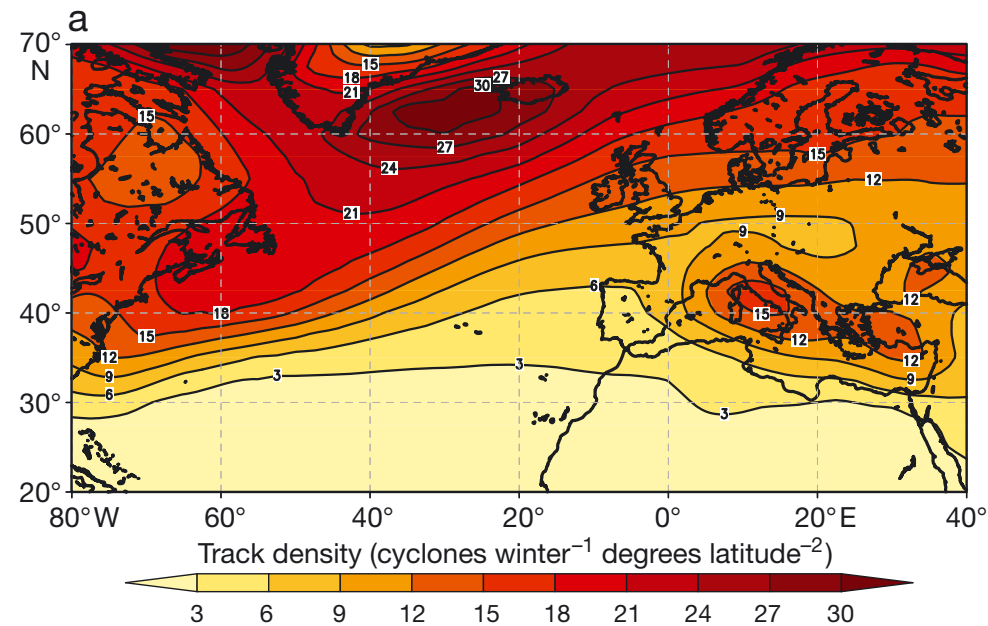

$\mathrm{b}$
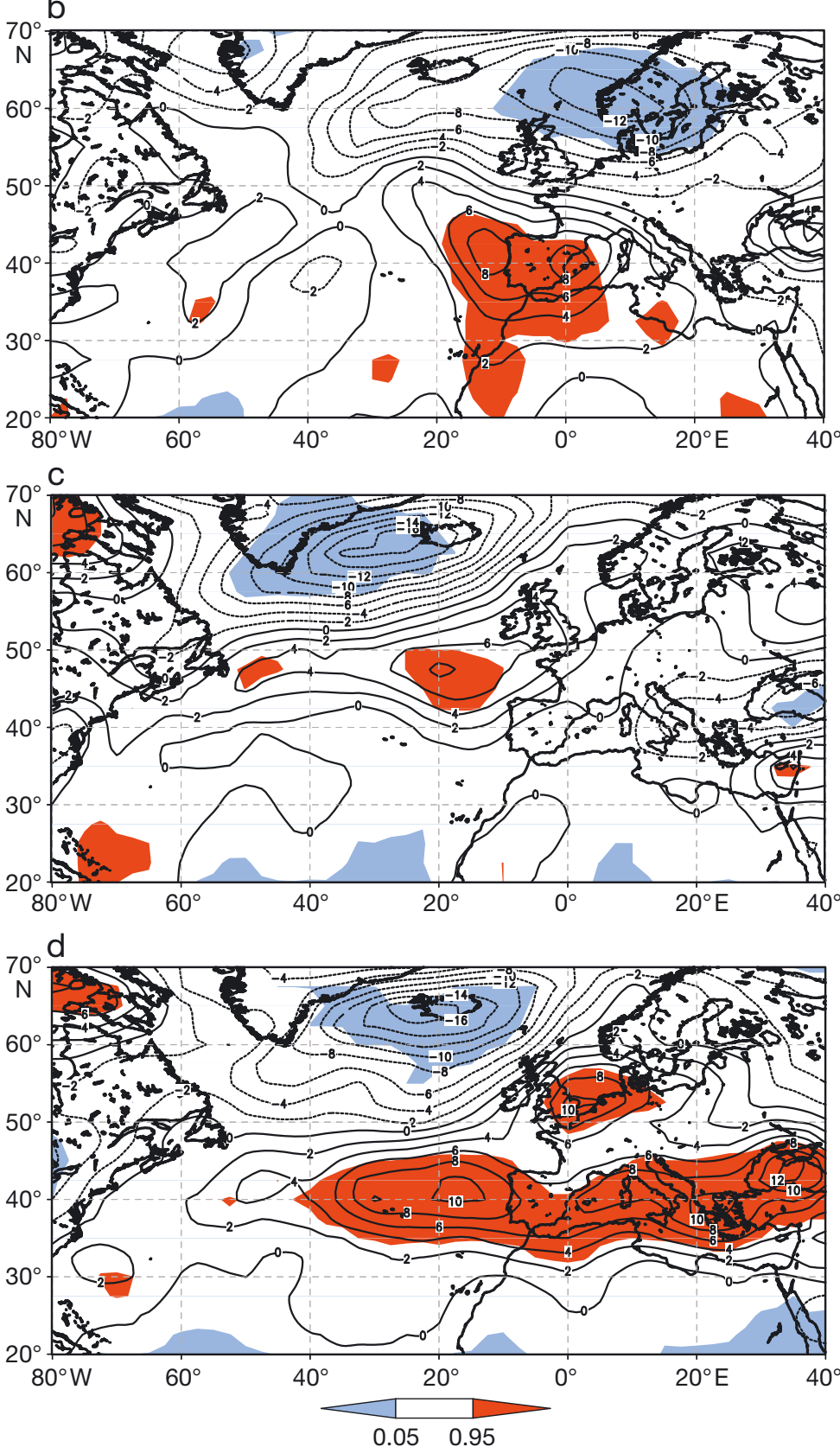

Fig. 7. (a) Cyclone track density field within the Euro-Atlantic sector for the winter 2010, in cyclones winter $^{-1}$ (deg. lat.) ${ }^{-2}$. Differences between the (b) 1996 winter, (c) 2001 winter, (d) 2010 winter and the corresponding baseline mean values for 19492009. Significant differences (5\% confidence level) are given in colour (blue for negative values, red for positive values)

increased number of $\mathrm{C}, \mathrm{S}$ and SW days, along with a decrease in the A flow. Previous studies documented that the $\mathrm{C}$ and SW-NW types are the most important contributors to winter precipitation over Portugal (e.g. Trigo \& DaCamara 2000). Increased frequencies of SW-NW flow are generally linked to a strengthening of the westerly flow component and with low pressure systems located northwards of Iberia (remote systems), whilst increased frequency of $\mathrm{C}$ flow is related to higher numbers of local low pressure systems (Figs. S2, S3). The reduced number of A flow days was favourable to the passage of cyclones near Iberia (Fig. 7), which are in turn commonly associated with $\mathrm{C}$ and S/SW flow over Portugal.

\subsection{Comparison with previous rainy winters}

We compared the 2010 winter with the 2 previous anomalous rainy winters of 1996 and 2001 to evaluate its severity. This selection is based on the strong positive precipitation anomalies for both winters (Fig. 3). The precipitation amounts for 1996, 2001 and 2010 are indicated in the distribution for each weather station (Fig. 2). Notably, the 2010 winter was substantially less rainy than the other 2 winters. In fact, the 1996 winter was the rainiest on record in Beja and the second rainiest in Lisboa, while the 2001 winter was the third rainiest in Porto. Thus, the 2010 winter was clearly not as rainy as the 1996 and 2001 winters. Accordingly, the winter mean runoffs for 1996 and 2001 are also significantly higher than those recorded in 2010, particularly for 2001 (Fig. 5). The lack of data in the Guadiana basin for 2001 and the suspicious low value recorded at 'Monte das Flores' inhibit a proper judgement for this river basin. These outcomes reveal that the 2010 winter was not particularly exceptional compared to previous wet winters, despite its high hydrological relevance. 
Table 2. Mean and SD frequencies of occurrence (in \%) of the 10 circulation weather types for all winter periods (DJF) in 1949-2010 and only for winters 1996, 2001 and 2010 (C: Cyclonic; A: Anti-cyclonic; and the 8 directional types, NE - N). Statistically significant (at $1 \%$ level) deviations in the frequencies relative to the 1949-2010 mean values are in bold (Student's $t$-test)

\begin{tabular}{|lcccccccccc|}
\hline$\%$ & C & A & NE & E & SE & S & SW & W & NW \\
\hline $\mathbf{1 9 4 9 - 2 0 1 0}$ & 7.25 & 42.32 & 4.23 & 6.22 & 5.35 & 4.36 & 10.32 & 10.56 & 5.70 & 3.70 \\
SD & 4.55 & 10.95 & 2.70 & 4.70 & 4.64 & 2.89 & 5.87 & 5.78 & 3.82 \\
$\mathbf{1 9 9 6}$ & $\mathbf{2 0 . 8 8} \uparrow$ & $\mathbf{1 9 . 7 8} \downarrow$ & $\mathbf{1 . 6 5}$ & 5.49 & 5.49 & 4.40 & $\mathbf{1 4 . 8 4} \uparrow$ & $\mathbf{1 8 . 1 3} \uparrow$ & 3.85 & 2.34 \\
$\mathbf{2 0 0 1}$ & 8.89 & $\mathbf{2 3 . 8 9} \downarrow$ & 4.44 & 4.44 & 2.78 & 0.56 & $\mathbf{2 4 . 4 4} \uparrow$ & $\mathbf{1 6 . 6 7} \uparrow$ & $\mathbf{1 2 . 2 2} \uparrow$ & $\mathbf{1 . 6 7} \downarrow$ \\
$\mathbf{2 0 1 0}$ & $\mathbf{1 1 . 6 7} \uparrow$ & $\mathbf{2 7 . 7 8} \downarrow$ & 4.44 & 5.56 & 3.33 & $\mathbf{9 . 4 4} \uparrow$ & $\mathbf{1 8 . 3 3} \uparrow$ & 10.56 & 5.00 & 3.89 \\
\hline
\end{tabular}

During the 2010 winter, the NAO index presented extremely negative NAO values, including the absolute minimum value in December (Fig. 8). Recordbreaking values were also identified for the AO, with February 2010 registering the absolute minimum value on record (-4.266). As such, the prevalence of an NAO negative phase throughout the 2010 winter is in plain agreement with the dynamical conditions described above. In spite of this clear linkage between the NAO negative phase and the anomalously wet 2010 winter, previous studies have also shown that precipitation in Portugal is not uniquely related to the NAO phase, but also to the East Atlantic Oscillation, and more specifically to the occurrence of low pressure systems westwards of the British Isles (e.g. Ulbrich et al. 1999, Santos et al. 2005). As the location of these anomalies is close to the nodal latitude of the NAO, they are typically associated with NAO indices close to zero. This fact explains the relatively normal NAO index values

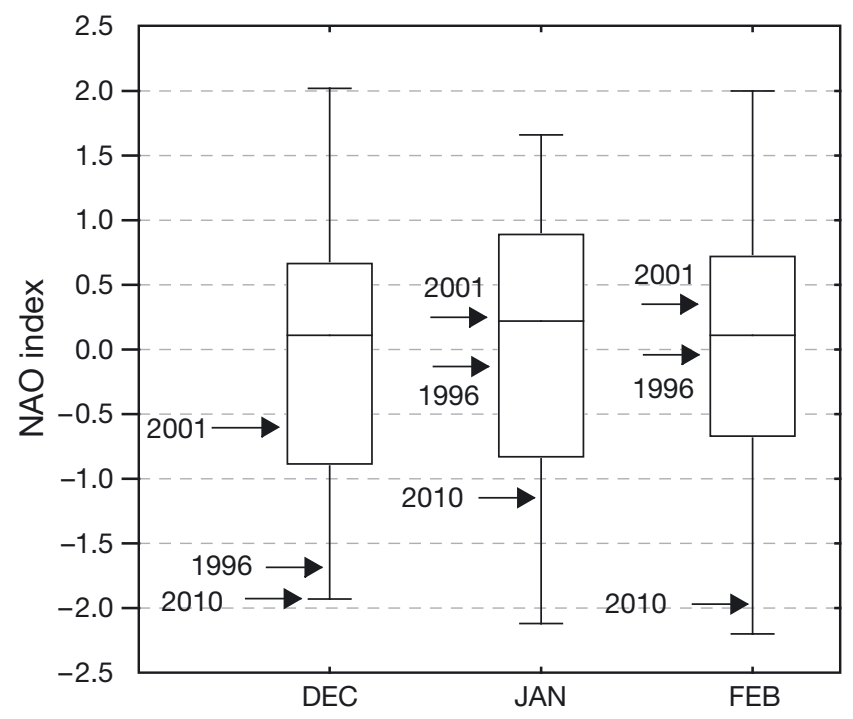

Fig. 8. Monthly mean NAO index in 1950-2010 and for December, January and February. Arrows indicate the respective values for the 1996, 2001 and 2010 winters. The corresponding percentiles are as follows: December 2001: 29\%, 1996: 3\%, 2010: 0\%; January 2001: 52\%, 1996: 38\%, 2010: $15 \%$; February 2001: $60 \%, 1996: 43 \%, 2010: 2 \%$ in 1996 and 2001 (Fig. 8), despite the extremely high precipitation amounts recorded throughout Portugal (Fig. 3b).

A comparative analysis of the MSLP mean anomalies for the 3 winters (Fig. 9) confirms the observed differences in terms of the NAO index (Fig. 8) and the occurrence of recurrent low pressure systems over the Eastern North Atlantic. The 2010 winter was characterised by a clear NAO negative phase, with strong positive (negative) anomalies in the Iceland low (Azores high) pressure area. Nonetheless, in the 1996 and 2001 winters, though featuring frequent low pressure systems north-westwards of Iberia (cf. Fig. 7b,c), a (negative) NAO MSLP pattern was not apparent. This explains the small projection into the NAO pattern and hence the near normal NAO index values. Although all 3 winters (1996, 2001 and 2010) featured a strong westerly flow component over Portugal (Fig. 9), the large-scale patterns were indeed remarkably different, as well as the corresponding NAO index values (Fig. 8).

The different dynamical conditions can also be attested by comparing the CWT frequencies, as well as the winter anomalies of the cyclone track density. In the 1996 winter, the negative pressure anomaly northwestwards of Portugal (Fig. 9) led to a strong increase in $\mathrm{C}$ flow days (local low pressure systems), accompanied by a strong decrease in A flow days, and to important increases in the frequencies of SW-W types. Additionally, a significant increase in the cyclone frequency over the Iberian Peninsula could be observed for 1996 winter (Fig. 7b). In the 2001 winter, the negative pressure anomaly was wider and weaker than in 1996, being also northwardly displaced (Fig. 9). This pattern yielded significant increases in the SW-NW types (enhanced westerly flow associated with remote low pressure systems, with a resulting decrease in the A type, but without a clear change in the $\mathrm{C}$ flow frequencies. This is confirmed by the enhanced number of cyclones northwest of Iberia for this winter (Fig. 7c). Note that the number of A flow days was actually higher in 2010 than in both 1996 and 2001, which is also in accordance with the relatively lower precipitation. 


\section{SUMMARY AND CONCLUDING REMARKS}

The aims of this study were (1) to objectively assess the significance of the 2010 winter in reversing the accumulated precipitation deficits in Portugal and (2) to isolate the changes in the large-scale atmospheric

a 1996 winter

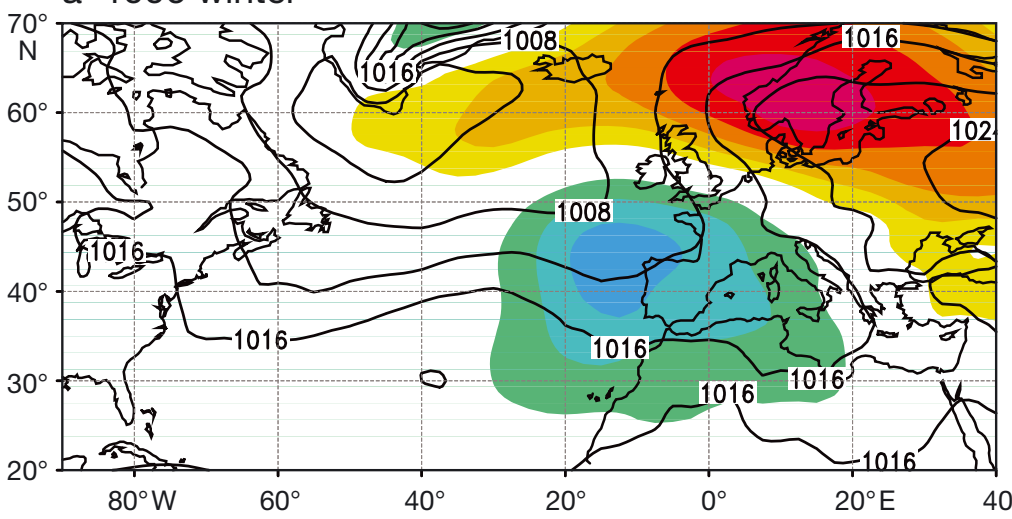

b 2001 winter

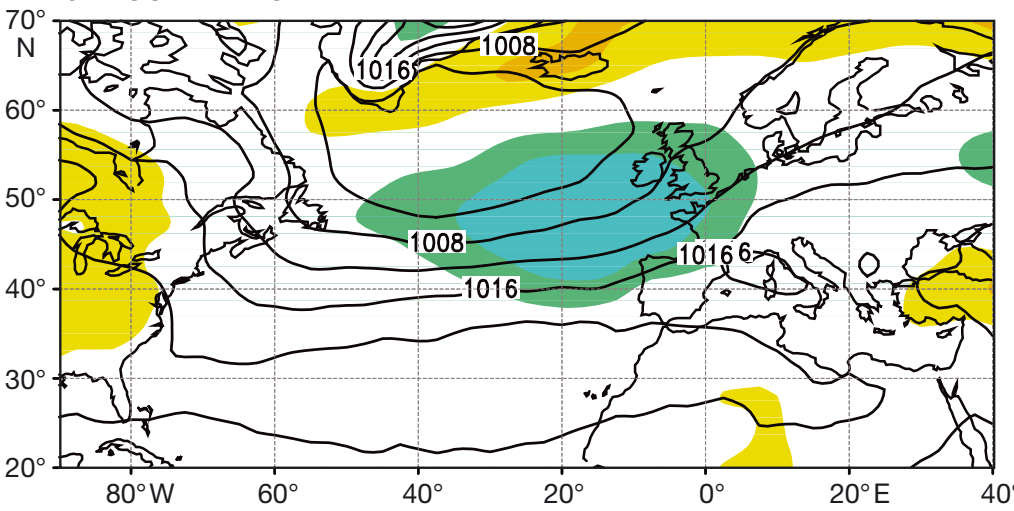

c 2010 winter

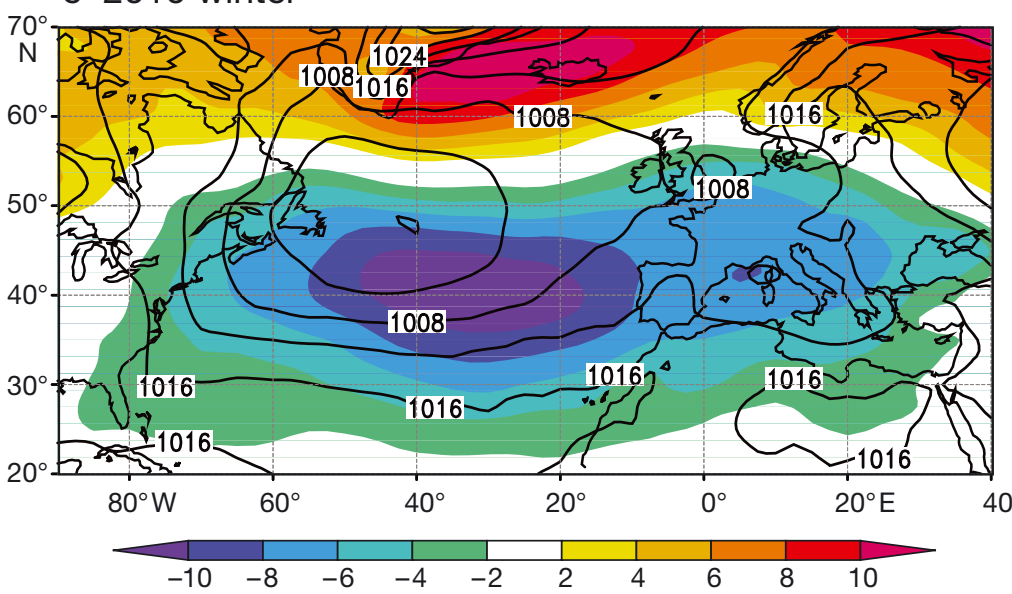

Fig. 9. Winter (DJF) mean sea level pressure fields (contours in $\mathrm{hPa}$ ) within the Euro-Atlantic sector for the (a) 1996, (b) 2001 and (c) 2010 winters Shading represents the corresponding departures relative to the long-term mean field (1949-2010) patterns underlying the anomalous wet conditions. In particular, we wanted to evaluate the severity of this winter compared to previous, similar rainy winters. The 2010 winter was reported by Portuguese authorities and media as being exceptionally rainy, with important beneficial socio-economic effects. These statements can be better understood when considering the strong seasonality (existence of pronounced wet/dry seasons) and irregularity (high inter-annual variability) of the precipitation regime in Portugal, which deeply control the entire hydrological cycle. All the same, the winter 2010 was indeed extremely important in reversing the accumulated precipitation deficits during the previous hydrological years.

The evaluation of the precipitation records confirmed that the 2010 winter was characterised by high precipitation amounts, being one of the wettest winters of the last decades. Accordingly, high runoffs and dam recharges were observed in the 4 major selected river basins, with the majority of the analysed dams above $80 \%$ of their maximum capacities at the end of February. Taking into account the accumulated precipitation deficits in the previous hydrological years since 2001, 2010 was shown to have a preponderant role in reversing this trend, with clear benefits to environmental and socioeconomic sectors.

The dynamical analysis showed that the anomalously high 2010 winter precipitation was associated with a prevalence of a predominantly zonal large-scale atmospheric flow over the eastern North Atlantic and Iberia. Our analysis documents the anomalously high frequency of synoptic disturbances and baroclinic instabilities westwards of Portugal, which decisively contributed to the establishment of rain-generating conditions over Portugal. Further, these changes are also in clear agreement with the negative phase of the NAO/AO. The frequencies of occurrence of some of the rainiest CWTs in Portugal $(\mathrm{C}, \mathrm{S}$ and SW) were also above average for this winter.

As mentioned above, a detailed comparison with the 2 anomalously wet winters in Portugal since 1990 (1996 and 2001) has also shown that the 2010 winter was objectively not extremely severe, in both meteorological and hydrological terms. In particular, precipitation at all 3 analysed weather stations was more extreme in 1996 and 2001 than in 2010. 
Although 1996 and 2001 were characterised by enhanced westerly flow over Portugal, the respective large-scale patterns were different and the associated NAO index values were much closer to zero (cf. Fig. 8). This result suggests that considering a single 2-way relationship between the NAO phase and precipitation in Portugal is a rather simplistic approach, particularly when estimating precipitation amounts only based on the NAO index (e.g. for seasonal prediction applications). Better results can be expected by considering additional factors; for example, Santos et al. (2005) showed that precipitation in Portugal is linked not only to the NAO pattern (NAO+ and NAO- precipitation regimes), but also to the EA pattern ( $\mathrm{C}$ and $\mathrm{E}$ regimes). In fact, precipitation in Portugal is best related to an NAO-like dipolar pattern, but shifted northeastwardly by about $15^{\circ}$ of latitude (Ulbrich et al. 1999).

Direct and indirect impacts of precipitation in Portugal on power generation and water management are particularly relevant. At the end of 2009, the leading Portuguese electric power production company, Electricidade De Portugal (EDP), reported an installed production capacity (conventional regime) of 9.675 MW, where $4.578 \mathrm{MW}$ were generated by 26 hydroelectric power plants (47\% of total electric production) and 5.097 MW via thermoelectric power generation. The increased hydroelectric power generation during the 2010 winter led to a decrease in fossil fuel consumption by thermoelectric power plants, and thus to a decrease in their respective imports. Thus, an improved seasonal predictability skill of winter precipitation would be relevant for medium-range planning, e.g. in the development of suitable and sustainable water management policies, for both human activities and energy production. This is particularly pertinent in a country largely dependent on fossil fuel imports, but where hydroelectric power generation is a growing feasible alternative. In fact, new dams are projected to increase hydroelectric potential from about 47 to $70 \%$ of total electric production in the next $10 \mathrm{yr}$.

Acknowledgements. We acknowledge the ECA\&D project (http://eca.knmi.nl) for providing the E-OBS dataset from the EU-FP6 ENSEMBLES project (http://ensembles-eu.metoffice. com). We thank R. Haas and S. Ulbrich (both University of Cologne) for their valuable help, and the anonymous reviewers for their constructive comments.

\section{LITERATURE CITED}

- Andrade C, Santos JA, Pinto JG, Corte-Real J (2010) The Empirical Forcing Function as a tool for the diagnosis of large-scale atmospheric anomalies. Ann Geophys 28:75-87

Buishand A, Brandsma T (1997) Comparison of circulation classification schemes for predicting temperature and precipitation in the Netherlands. Int J Climatol 17:875-889
Fink AH, Brücher T, Ermert V, Krüger A, Pinto JG (2009) The European storm Kyrill in January 2007: synoptic evolution and considerations with respect to climate change. Nat Hazards Earth Syst Sci 9:405-423

- García-Herrera R, Hernández E, Barriopedro D, Trigo RM, Trigo IF, Mendes MA (2007) The outstanding 2004/05 drought in the Iberian Peninsula: associated atmospheric circulation. J Hydrometeorol 8:483-498

García-Herrera R, Díaz J, Trigo RM, Luterbacher J, Fischer EM (2010) Review of the European summer heat wave of 2003. Crit Rev Environ Sci Technol 40:267-306

Goodess CM, Jones PD (2002) Links between circulation and changes in the characteristics of the Iberian rainfall. Int $\mathrm{J}$ Climatol 22:1593-1615

Haylock MR, Hofstra N, Klein Tank AMG, Klok EJ, Jones PD, New M (2008) A European daily high-resolution gridded dataset of surface temperature and precipitation. J Geophys Res 113:D20119 doi:10.1029/2008JD010201

Hurrell JW (1995) Decadal trends in the North Atlantic Oscillation: regional temperatures and precipitation. Science 269:676-679

Jenkinson AF, Collison FP (1977) An initial climatology of gales over the North Sea. Synoptic Climatology Branch Memo no. 62. Met. Office, Bracknell, UK

$>$ Jones PD, Hulme M, Briffa KR (1993) A comparison of Lamb circulation types with an objective classification scheme. Int J Climatol 13:655-663

Kistler R, Kalnay E, Collins W, Saha S and others (2001) The NCEP/NCAR 50-year reanalysis: monthly-means CDROM and documentation. Bull Am Meteorol Soc 82: $247-267$

Klein Tank AMG, Wijngaard JB, Können GP, Böhm R and others (2002) Daily dataset of 20th-century surface air temperature and precipitation series for the European Climate Assessment. Int J Climatol 22:1441-1453

Lamb HH (1972) British Isles weather types and a register of the daily sequence of circulation patterns, 1861-1971. Geophys Meml 116. HMSO, London

Murray RJ, Simmonds I (1991) A numerical scheme for tracking cyclone centres from digital data. Part I: development and operation of the scheme. Aust Meteorol Mag 39: 155-166

Paredes D, Trigo RM, García-Herrera R, Trigo IF (2006) Understanding precipitation changes in Iberia in early spring: weather typing and storm-tracking approaches. J Hydrometeorol 7:101-113

Pereira J, Correia AV, Correia AP, Branco M and others (2002) Forests and biodiversity. In: Santos FD, Forbes K, Moita $\mathrm{R}$, (eds) Climate change in Portugal: scenarios, impacts and adaptation measures. SIAM project. Gradiva, Lisbon, p 363-414

> Pinto JG, Spangehl T, Ulbrich U, Speth P (2005) Sensitivities of a cyclone detection and tracking algorithm: individual tracks and climatology. Meteorol Z 14:823-838

> Pinto JG, Ulbrich U, Leckebusch GC, Spangehl T, Reyers M, Zacharias S (2007) Changes in storm track and cyclone activity in three SRES ensemble experiments with the ECHAM5/MPI-OM1 GCM. Clim Dyn 29:195-210

Sáenz J, Zubillaga J, Rodríguez-Puebla C (2001) Interannual variability of winter precipitation in northern Iberian Peninsula. Int J Climatol 21:1503-1513

Santos JA, Corte-Real J, Leite SM (2005) Weather regimes and their connection to the winter rainfall in Portugal. Int J Climatol 25:33-50

Santos J, Corte-Real J, Leite S (2007a) Atmospheric largescale dynamics during the 2004-2005 winter drought in Portugal. Int J Climatol 27:571-586 
Santos J, Corte-Real J, Ulbrich U, Palutikof J (2007b) European winter precipitation extremes and surface largescale circulation: a coupled model and its scenarios. Theor Appl Climatol 87:85-102

Santos JA, Pinto JG, Ulbrich U (2009a) On the development of strong ridge episodes over the eastern North Atlantic. Geophys Res Lett 36:L17804. doi:10.1029/2009GL039086

Santos J, Andrade C, Corte-Real J, Leite S (2009b) The role of large-scale eddies in the occurrence of winter precipitation deficits in Portugal. Int J Climatol 29:1493-1507

Simmonds I, Murray RJ, Leighton RM (1999) A refinement of cyclone tracking methods with data from FROST. Aust Met Mag (Spec Edn) 1999:35-49

Thompson DWJ, Wallace JM (1998) The Artic Oscillation signature in the wintertime geopotential height and temperature fields. Geophys Res Lett 25:1297-1300

Trigo RM, DaCamara C (2000) Circulation weather types and their influence on the precipitation regime in Portugal. Int J Climatol 20:1559-1581

Trigo RM, Pozo-Vázquez D, Osborn TJ, Castro-Díez Y, GámizFortis S, Esteban-Parra MJ (2004) North Atlantic Oscillation influence on precipitation, river flow and water resources in the Iberian Peninsula. Int J Climatol 24:925-944

Editorial responsibility: Bryson Bates, Wembley, Australia
Turc L (1954) Le bilan d'eau des sols: relations entre les precipitations, l'évaporation et l'écoulement. Ann Agron 4: 491-595

Ulbrich U, Christoph M, Pinto JG, Corte-Real J (1999) Dependence of winter precipitation over Portugal on NAO and baroclinic wave activity. Int J Climatol 19:379-390

> Ulbrich U, Brücher T, Fink AH, Leckebusch GC, Krüger A, Pinto JG (2003) The Central European floods in August 2002. Part I: rainfall periods and flood development. Weather 58:371-377

> Vicente-Serrano SM (2006a) Differences in spatial patterns of drought on different time scales: an analysis of the Iberian Peninsula. Water Resour Manag 20:37-60

Vicente-Serrano SM (2006b) Spatial and temporal analysis of droughts in the Iberian Peninsula (1910-2000). Hydrol Sci J 51:83-97

Xoplaki E, Gonzalez-Rouco FJ, Luterbacher J, Wanner H (2004) Wet season Mediterranean precipitation variability: influence of large-scale dynamics. Clim Dyn 23:63-78

Zorita E, Kharin V, von Storch H (1992) The atmospheric circulation and sea surface temperature in the North Atlantic area in winter: their interaction and relevance for Iberian precipitation. J Clim 5:1097-1108

Submitted: July 2, 2010; Accepted: October 5, 2010

Proofs received from author(s): January 18, 2011 